\title{
The Effect of Fabrication Conditions on the Morphology and Photocatalytic Activity of Bismutite $\mathrm{Bi}_{2} \mathrm{O}_{2} \mathrm{CO}_{3}$ Particles
}

\author{
Hong Hu${ }^{*}$, Changlong Xiao ${ }^{2}$ \\ ${ }^{1}$ Department of Applied Chemistry, Nanjing Polytechnic Institute, Nanjing, China \\ ${ }^{2}$ School of Chemistry, Monash University, Clayton, Australia \\ Email: ‘hhu@njpi.edu.cn
}

How to cite this paper: $\mathrm{Hu}, \mathrm{H}$. and Xiao, C.L. (2017) The Effect of Fabrication Conditions on the Morphology and Photocatalytic Activity of Bismutite $\mathrm{Bi}_{2} \mathrm{O}_{2} \mathrm{CO}_{3}$ Particles. Open Journal of Physical Chemistry, $7,1-8$.

https://doi.org/10.4236/ojpc.2017.71001

Received: December 2, 2016

Accepted: January 6, 2017

Published: January 9, 2017

Copyright $\odot 2017$ by authors and Scientific Research Publishing Inc. This work is licensed under the Creative Commons Attribution International License (CC BY 4.0). http://creativecommons.org/licenses/by/4.0/

\begin{abstract}
In this study, three-dimensional bismutite $\mathrm{Bi}_{2} \mathrm{O}_{2} \mathrm{CO}_{3}$ nanoparticels (BSC NPs) have been synthesized through a facile hydrothermal treatment under mild conditions. The reaction temperatures and $\mathrm{NaOH}$ concentration have a vital influence on the physical and photocatalytic properties of the obtained BSC NPs. The crystal structure, morphology, chemical composition, specific surface area and photoresponse of as-obtained catalysts were characterized by $\mathrm{X}$-ray diffraction, Scanning electron microsprctrosopy, Energy-dispersive spectroscopy, $\mathrm{N}_{2}$ adsorption/desorption isotherms and UV-Vis spectra, respectively. Furthermore, Rhodamine $6 \mathrm{G}$ was used as model reaction to evaluate the photocatalytic activity of BSC NPs. As a result, there was no obvious effect of hydrothermal reaction temperature and $\mathrm{NaOH}$ concentration on phase structure and UV-visible light response; while the morphology, BET surface area and photoactivity were affected by hydrothermal reaction temperature and $\mathrm{NaOH}$ concentration.
\end{abstract}

\section{Keywords}

$\mathrm{Bi}_{2} \mathrm{O}_{2} \mathrm{CO}_{3}$ Particles, R6G Degradation, Photocatalytic Activity, Hydroxyl Radical

\section{Introduction}

With the increasingly serious environmental problems and dispassion of fossil fuels, the elimination of hazardous chemicals through photochemical degradation technology has attracted enormous research interest [1]. In terms of photo-oxidation approach, it has many unique advantages including mild reaction conditions, low-energy consumption and environmental friendly. However, the 
photo-oxidation reactions suffer from sluggish kinetics and great energy barrier need to be overcome to achieve a appreciate conversion efficiency.

In recent years, the bismuth-based compounds have attracted much research interest and show excellent performance in a variety of fields such as biomedical fields, solid oxide fuel cells, oxygen sensors, varistors or electrochromic devices as well as environmental science [2]-[8]. Specifically, BSC show significant potential in photocatalysis owing to its excellent photochemical properties according to early reports. For example, Zhang et al. have synthesized 3D BSC nanocrystals for selective adsorption and separation of dyes [9]. Nevertheless, the effect of fabrication conditions of BSC on the photocatalysis performance has been investigated yet [10]. Therefore, the study of fabrication conditions which may have crucial effect on the morphology and photocatalytic properties is necessary [11].

About $1 \%-20 \%$ of the total world textile dyes and other industrial dyes are released to waste water [12]. Dye wastewater is typically characterized by strong color, stability and, biotoxicity and carcinogenic effects even at very low concentration, which is harmful to our health and environment [13] [14]. The removal of dyes from waste water has received considerable attention. Compared with traditional physical techniques such as adsorption, ultrafiltration, reverse osmosis and ion exchange that would result in secondary pollution, photocatalytic oxidation can degrade dyes to $\mathrm{CO}_{2}$ and $\mathrm{H}_{2} \mathrm{O}$ [12]. Rhodamine 6G (R6G) is a typical dye that is chemically stable and poorly biodegradable in waste water. In this paper, we therefore selected R6G as model pollutant to determine the photocatalytic activity. The influence of fabrication conditions on the physical properties and photocatalytic activity of BSC were investigated.

\section{Experimental}

\subsection{Catalyst Preparation}

Bismuth nitrate $\left(\mathrm{Bi}\left(\mathrm{NO}_{3}\right)_{3}\right)$, urea $\left(\mathrm{CO}\left(\mathrm{NH}_{2}\right)_{2}\right)$ and sodium hydroxide $(\mathrm{NaOH})$ were of analytical grade and used without any further purification. Deionized water was used in the whole fabricating process. Three-dimensional bismutite $\mathrm{Bi}_{2} \mathrm{O}_{2} \mathrm{CO}_{3}$ (BSC) was synthesized by a hydrothermal reaction under mild conditions. $10 \mathrm{mmol}$ of bismuth nitrate and $40 \mathrm{mmol}$ of urea were dissolved in $30 \mathrm{ml}$ of 0.5 - $2 \mathrm{M}$ sodium hydroxide solution. The mud mixture was stirred for $2 \mathrm{~h}$ at room temperature with a stirring rate of $600 \mathrm{rpm}$, and then poured into a Teflon autoclave. The autoclave was put in an oven and allowed to be heated at $120^{\circ} \mathrm{C}$ $160^{\circ} \mathrm{C}$ for $6 \mathrm{~h}$ under autogenous pressure, and then cooled to room temperature. The precipitates were collected and washed with deionized water and absolute ethanol for 3 times each to remove any residual ions. The final product was dried at $80^{\circ} \mathrm{C}$ for $6-12 \mathrm{~h}$ for further use. The BSC samples synthesized using 0.1 $\mathrm{M} \mathrm{NaOH}$ and at $120^{\circ} \mathrm{C}, 140^{\circ} \mathrm{C}$, and $160^{\circ} \mathrm{C}$ were noted $\mathrm{BSC} 1, \mathrm{BSC} 2, \mathrm{BSC} 3$, respectively; and $\mathrm{BSC} 4, \mathrm{BSC} 5, \mathrm{BSC} 6$ were prepared at hydrothermal temperature of $120^{\circ} \mathrm{C}$ using $0.5,1,2 \mathrm{M} \mathrm{NaOH}$ respectively. 


\subsection{Characterizations}

X-ray diffraction (XRD, D8 ADVANCE) with $\mathrm{Cu} \mathrm{K} \alpha$ radiation $(25 \mathrm{~mA}$ and 40 $\mathrm{kV}$ ) was used to investigate the structure of the BSC samples. The morphology and composition of the samples were characterized by a scanning electron microscope (SEM, JEOL JSM-7001F) and Energy dispersive spectrometer (EDS) that is attached to JEOL JSM-7001F. UV-Vis absorption spectra of BSC were scanned by a spectrophotometer in the range of $200-800 \mathrm{~nm}$ (UV-VIS, SHIMADZU UV-2600). The specific surface area, pore size distribution and pore volume were measured by Tristar II3020 and the specific surface area was calculated with the Brunauer-Emmett-Teller (BET) method (Analysis Adsorptive: liquid $\mathrm{N}_{2}$ ). The adsorbed amount at a $\mathrm{P} / \mathrm{P}_{0}$ value of 0.99 was used to estimate the total pore volume. The Barrett-Joyner-Halenda (BJH) method was utilized to calculate the average pore diameter from desorption branch of the isotherm. The as-obtained catalysts were used for photodegradation of R6G and the corresponding photocatalytic activity was investigated by UV-vis spectroscopy.

\section{Results and Discussion}

\subsection{Crystal Structure}

Figure 1 shows the X-ray diffraction patterns (XRD) of as-obtained BSC sample synthesized at different conditions. A series of diffraction peaks located at $12.9^{\circ}$

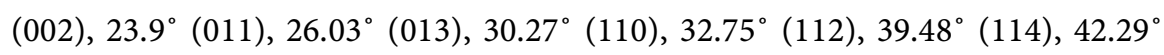
(020), $47.00^{\circ}(022)$ and $56.91^{\circ}$ (123) can be observed, which are ascribed to the tetragonal phase of $\mathrm{Bi}_{2} \mathrm{O}_{2} \mathrm{CO}_{3}$ (JCPDS: 41-1488). According to the XRD pattern, no obvious alteration and shift can be detected for all 6 BSC samples (BSC1 BSC6), indicating hydrothermal temperature and the concentration of $\mathrm{NaOH}$ have no distinct effects on the structure of BSC.

\subsection{Morphologies}

Figure 2 shows the morphology of different BSC samples. Similarly, no obvious

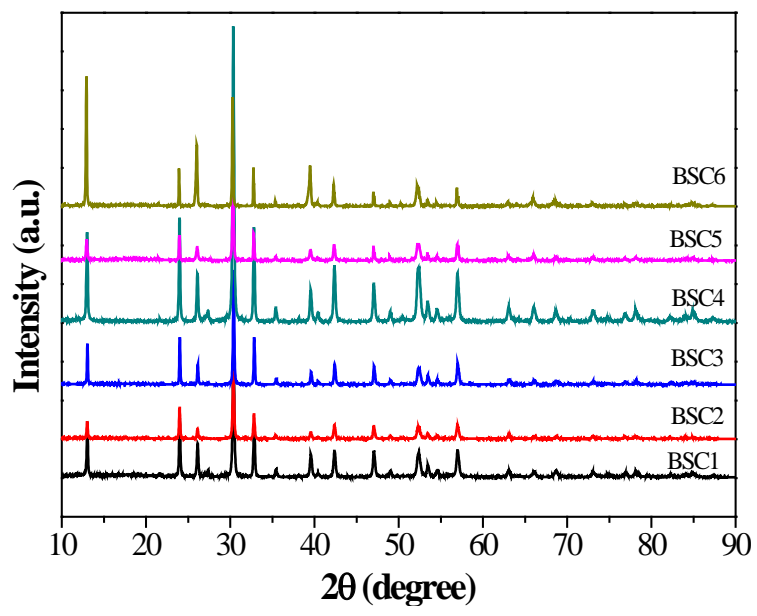

Figure 1. XRD patterns of various BSC samples prepared at different conditions. 

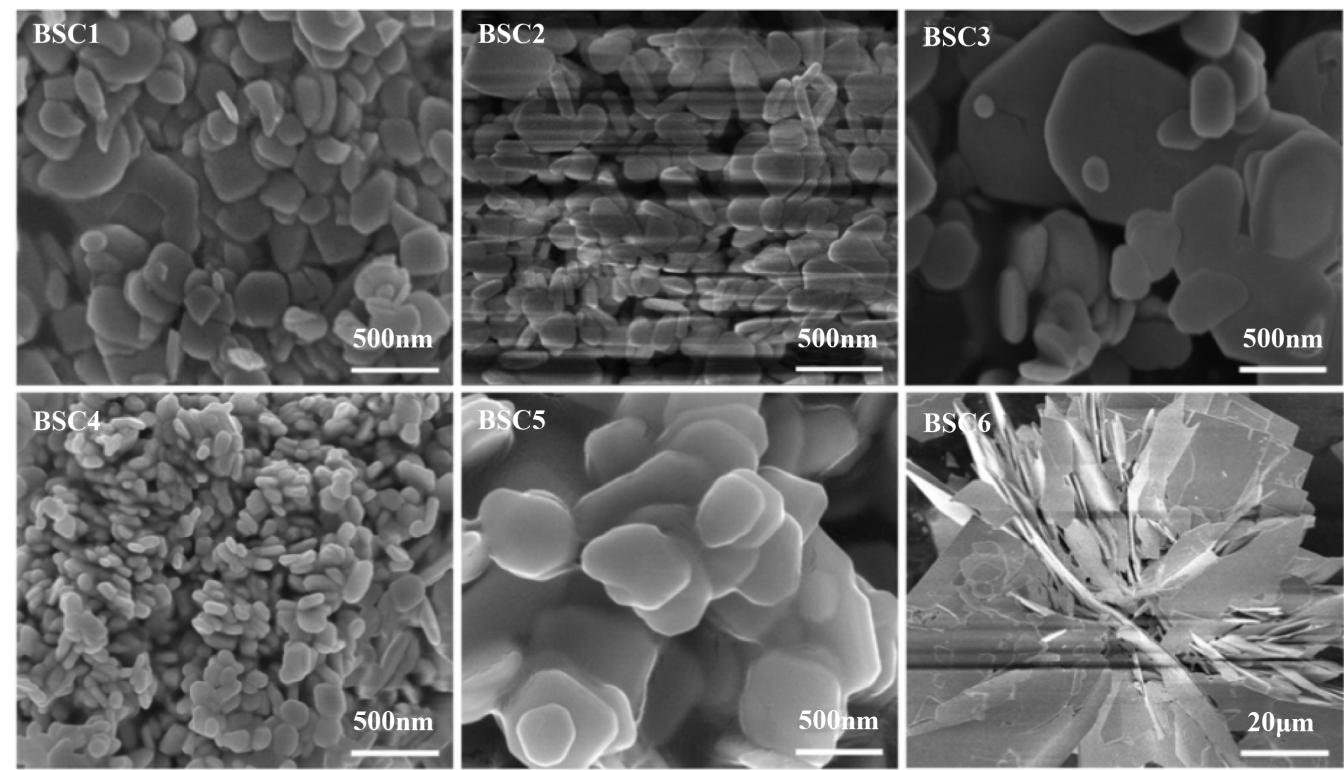

Figure 2. SEM images of BSC samples at different fabrication conditions.

change can be observed for 6 BSC samples, further illustrating ignorable effect of hydrothermal temperature on the morphology. However, it can be seen that the crystallite size gradually becomes non-uniform with the increase of thermal treatment temperature. As a consequence, the optimal temperature is $120^{\circ} \mathrm{C}$. However, the $\mathrm{NaOH}$ concentration shows significant effect on the morphology of the BSC samples. It can be clearly seen that, the BSC particles change into square plates leading to larger sizes with the increase of $\mathrm{NaOH}$ concentration. In the hydrothermal reaction, $[\mathrm{OH}]^{-}$ions affects the nucleation and growth of oxide crystals. It has been inferred that $[\mathrm{OH}]^{-}$ions attach on (110) and (110) facets of oxide crystals, which may hinder the growth of these facets. Therefore, the morphology of BSC crystals gradually changes into square plates. On the other hand, $[\mathrm{OH}]^{-}$ions reacts with $\mathrm{Bi}\left(\mathrm{NO}_{3}\right)_{3}$ to produce $\mathrm{Bi}(\mathrm{OH})_{3}$ or $\left[\mathrm{Bi}(\mathrm{OH})_{4}\right]^{-}$, which are then dehydrated to $\mathrm{BiOOH}$. Meanwhile, $\mathrm{NaOH}$ reacts with urea generate sodium carbonate, which speeds up the hydrolysis of urea [9]. Herein, the particle size of BSC becomes larger and even aggregates together with increasing of $\mathrm{NaOH}$ concentration. Because the all the as-obtained BSC samples show similar crystal structure, BSC1 was selected as a representative to analyze elemental composition. Figure 3 shows the energy dispersive $\mathrm{x}$-ray spectrum of BSC1, indicating the existence of $\mathrm{Bi}, \mathrm{C}$, O elements and among the entire BSC NPs.

\subsection{Surface Area and Pore Size Distribution}

BET surface area, pore size distribution and pore volume of all as-obtained sample are listed in Table 1. Apparently, the BET surface area and pore volume decrease with the increase of hydrothermal temperature, which is in well agreement with the result observed in SEM images. However, there is no distinct change in BET surface area and pore volume of BSC1 and BSC4 with the change of $\mathrm{NaOH}$ concentration (from 0.1 to $0.5 \mathrm{M}$ ). 


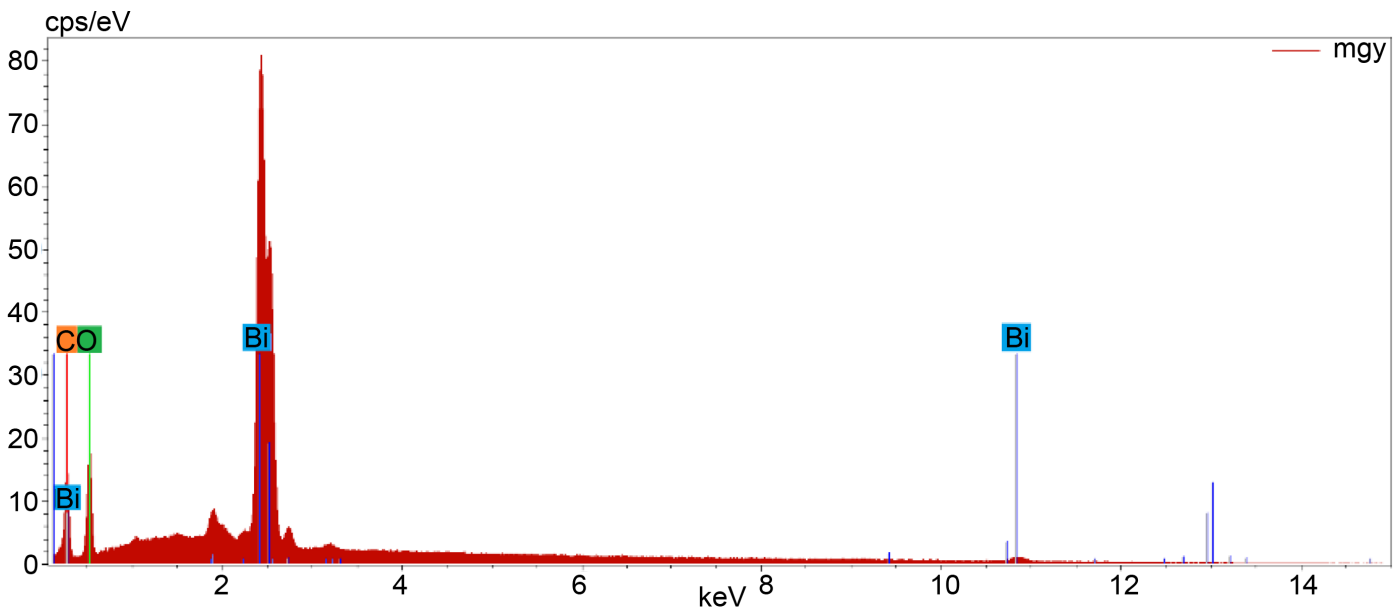

Figure 3. The EDS elemental composition of BSC1.

Table 1. Macroscopic physical properties of BSC.

\begin{tabular}{ccccccc}
\hline Samples & BSC1 & BSC2 & BSC3 & BSC4 & BSC5 & BSC6 \\
\hline $\mathrm{S}_{\mathrm{BET}}\left(\mathrm{m}^{2} / \mathrm{g}\right)$ & 6.27 & 5.59 & 2.91 & 6.54 & 5.58 & 1.06 \\
Pore volume $\left(\mathrm{cm}^{3} / \mathrm{g}\right)^{\mathrm{a}}$ & 0.038 & 0.021 & 0.012 & 0.032 & 0.018 & 0.0036 \\
Average pore size $(\mathrm{nm})$ & 25.3 & 16.3 & 16.9 & 20.6 & 13.4 & 42.8 \\
\hline
\end{tabular}

${ }^{\mathrm{a}}$ Volume of pores between $1.7 \mathrm{~nm}$ and $300 \mathrm{~nm}$.

However, the BET surface area decreases sharply when $\mathrm{NaOH}$ concentration increases to 1 and $2 \mathrm{M}$, which attributes to the particle aggregation along with $\mathrm{NaOH}$ concentration increasing. This further confirms that $\mathrm{NaOH}$ plays dual function. The average pore diameter, calculated by the BJH method based on the desorption branch, shows that the BSC samples have a very clear mesoporous structure with pore size centered at 13.4 and $42.8 \mathrm{~nm}$.

\subsection{Photocatalytic Activity}

Figure 4 shows UV-Vis diffuse reflectance spectra of different photocatalysts BCS1 - BSC6. The results indicate that different BSC samples have almost same light response.

The photodegration reaction was carried out at room temperature and the $\mathrm{pH}$ was adjusted by adding $0.1 \mathrm{M} \mathrm{HCl}$. As reported in our previous work [15] R6G is positively charged in the $\mathrm{pH}$ range of below 6.0, BSC surfaces are negatively charged with a zeta potential of about $-40 \mathrm{mV}$. There is bigger binding force between R6G and BSC when the $\mathrm{pH}$ is below 6 . The results in Figure 5 indicate that all photocatylysts show high photoactivity. However BSC3 and BSC6 have a little lower photoactivity. This is attributed to the low BET surface area of BSC3 and BSC6, which would decrease the contact surface between catalyst and reactant. The photocatalyst reacts with water to form hydroxyl radical $(\cdot \mathrm{OH})$, which can rapidly attacks pollutants at the surface and in solution as well. Hydroxyl radical $(\cdot \mathrm{OH})$ is a very powerful oxidant with the oxidation potential of $2.8 \mathrm{~V}$ (NHE). Photocatalyst can mineralize organic pollutants into $\mathrm{CO}_{2}, \mathrm{H}_{2} \mathrm{O}$ and so on [16] [17]. 


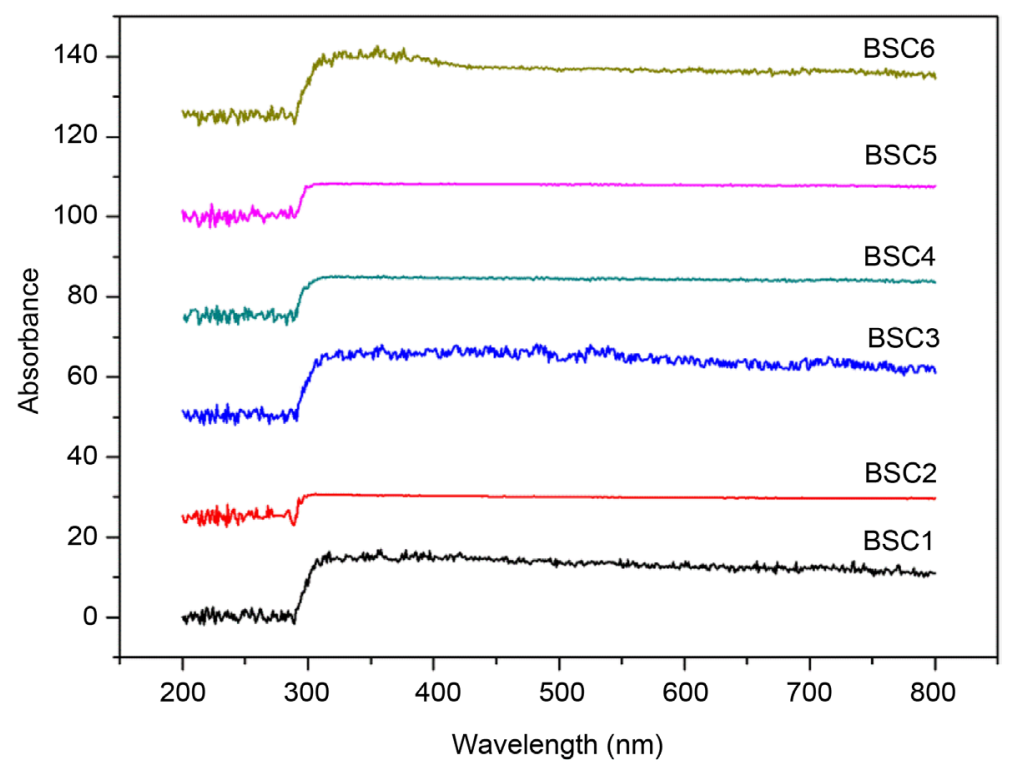

Figure 4. UV-Vis diffuse reflectance spectra of different photocatalysts.

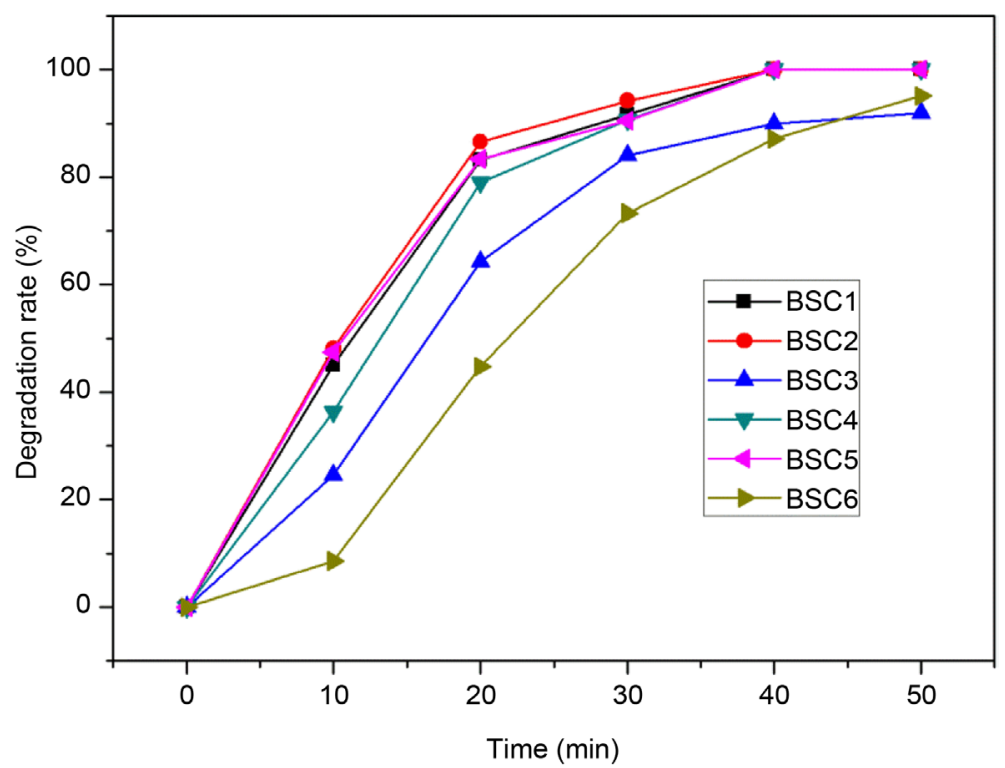

Figure 5. Photodegradation of R6G using different catalysts.

\section{Conclusion}

Three-dimensional bismutite BSC were prepared through a hydrothermal synthesis with bismuth nitrate, urea and sodium hydroxide under mild conditions. There are no obvious effects of hydrothermal reaction temperature and $\mathrm{NaOH}$ concentration on the structure and light response of BSC. However, the particle size, BET surface area, pore volume and photoactivity decrease with the increase of hydrothermal reaction temperature and $\mathrm{NaOH}$ concentration. It suggestes that the concentration of $\mathrm{NaOH}$ plays dual role in the fabrication of BSC.

\section{Acknowledgements}

Hong $\mathrm{Hu}$ is grateful to the Department of Education of Jiangsu Province China 
for sponsoring her visiting research at Monash University through "Jiangsu Overseas Research \& Training Program for University Prominent Young \& Middleaged Teachers and Presidents".

\section{References}

[1] Friedmann, D., Mendive, C. and Bahnemann, D. (2010) $\mathrm{TiO}_{2}$ for Water Treatment: Parameters Affecting the Kinetics and Mechanisms of Photocatalysis.Applied Catalysis B-Environmental, 99, 398-406. https://doi.org/10.1016/j.apcatb.2010.05.014

[2] Cao, X.F., Zhang, L., Chen, X.T. and Xue, Z.L. (2011) Persimmon-Like $(\mathrm{BiO})_{2} \mathrm{CO}_{3}$ Microstructures: Hydrothermal Preparation, Photocatalytic Properties and Their Conversion into $\mathrm{Bi}_{2} \mathrm{~S}_{3}$. Cryst Eng Comm, 13, 1939-1945.

https://doi.org/10.1039/C0CE00324G

[3] Yang, J., Dai, S., Zhou, Y., Wen, L., Hu, L. and Jiang, Z. (2003) Spectroscopic Properties and Thermal Stability of Erbium-Doped Bismuth-Based Glass for Optical Amplifier. Journal of Applied Physics, 93, 977-983. https://doi.org/10.1063/1.1531840

[4] Dong, F., Ho, W.K., Lee, S.C., Wu, Z., Fu, M., Zou, S. and Huang, Y. (2011) Template-Free Fabrication and Growth Mechanism of Uniform $(\mathrm{BiO})_{2} \mathrm{CO}_{3}$ Hierarchical Hollow Microspheres with Outstanding Photocatalytic Activities under Both UV and Visible Light Irradiation. Journal of Materials Chemistry, 21, 12428-12436. https://doi.org/10.1039/c1jm11840d

[5] Zheng, Y., Duan, F., Chen, M. and Xie, Y. (2010) Synthetic $\mathrm{Bi}_{2} \mathrm{O}_{2} \mathrm{CO}_{3}$ Nanostructures: Novel Photocatalyst with Controlled Special Surface Exposed. Journal of Molecular Catalysis A: Chemical, 317, 34-40. https://doi.org/10.1016/j.molcata.2009.10.018

[6] Briand, G.G. and Burford, N. (1999) Bismuth Compounds and Preparations with Biological or Medicinal Relevance. Chemical Reviews, 99, 2601-2658.

https://doi.org/10.1021/cr980425s

[7] Cheng, G., Yang, H., Rong, K., Lu, Z., Yu, X. and Chen, R. (2010) Shape-Controlled Solvothermal Synthesis of Bismuth Subcarbonate Nanomaterials. Journal of Solid State Chemistry, 183, 1878-1883. https://doi.org/10.1016/j.jssc.2010.06.004

[8] Zhao, T., Zai, J., Xu, M., Zou, Q., Su, Y., Wang, K. and Qian, X. (2011) Hierarchical $\mathrm{Bi}_{2} \mathrm{O}_{2} \mathrm{CO}_{3}$ Microspheres with Improved Visible-Light-Driven Photocatalytic Activity. Cryst Eng Comm, 13, 4010-4017. https://doi.org/10.1039/c1ce05113j

[9] Zhang, X., Zheng, Y., McCulloch, D.G., Yeo, L.Y., Friend, J.R. and MacFarlane, D.R. (2014) Controlled Morphogenesis and Self-Assembly of Bismutite Nanocrystals into Three-Dimensional Nanostructures and Their Applications. Journal of Materials Chemistry A, 2, 2275-2282. https://doi.org/10.1039/C3TA14587E

[10] Liu, S., Tu, Y. and Dai, G. (2014) The Effects of Citrate Ion on Morphology and Photocatalytic Activity of Flower-Like $\mathrm{Bi}_{2} \mathrm{O}_{2} \mathrm{CO}_{3}$. Ceramics International, 40, 23432348. https://doi.org/10.1016/j.ceramint.2013.08.004

[11] Huang, H., Tian, N., Jin, S., Zhang, Y. and Wang, S. (2014) Syntheses, Characterization and Nonlinear Optical Properties of a Bismuth Subcarbonate $\mathrm{Bi}_{2} \mathrm{O}_{2} \mathrm{CO}_{3}$. Solid State Sciences, 30, 1-5. https://doi.org/10.1016/j.solidstatesciences.2014.01.010

[12] Konstantinou, I.K. and Albanis, T.A. (2004) $\mathrm{TiO}_{2}$-Assisted Photocatalytic Degradation of Azo Dyes in Aqueous Solution: Kinetic and Mechanistic Investigations: A Review. Applied Catalysis B: Environmental, 49, 1-14. https://doi.org/10.1016/j.apcatb.2003.11.010

[13] Bao, N., Li, Y., Wei, Z., Yin, G. and Niu, J. (2011) Adsorption of Dyes on Hierar- 
chical Mesoporous $\mathrm{TiO}_{2}$ Fibers and Its Enhanced Photocatalytic Properties. The Journal of Physical Chemistry C, 115, 5708-5719. https://doi.org/10.1021/jp1100939

[14] Jing, L., Wang, J., Qu, Y. and Luan, Y. (2009) Effects of Surface-Modification with $\mathrm{Bi}_{2} \mathrm{O}_{3}$ on the Thermal Stability and Photoinduced Charge Property of Nanocrystalline Anatase $\mathrm{TiO}_{2}$ and Its Enhanced Photocatalytic Activity. Applied Surface Science, 256, 657-663. https://doi.org/10.1016/j.apsusc.2009.08.037

[15] Hu, H., Xiao, C., Lin, X., Chen, K., Li, H. and Zhang, X. (2016) Controllable Fabrication of Heterostructured $\mathrm{Au} / \mathrm{Bi}_{2} \mathrm{O}_{3}$ with Plasmon Effect for Efficient Photodegradation of Rhodamine 6G. Journal of Experimental Nanoscience, 1-12. https://doi.org/10.1080/17458080.2016.1255790

[16] Xiao, C., Li, Y., Lu, X. and Zhao, C. (2016) Bifunctional Porous $\mathrm{NiFe} / \mathrm{NiCo}_{2} \mathrm{O}_{4} / \mathrm{Ni}$ Foam Electrodes with Triple Hierarchy and Double Synergies for Efficient Whole Cell Water Splitting. Advanced Functional Materials, 26, 3515-3523. https://doi.org/10.1002/adfm.201505302

[17] Zhang, X., Yao, J., Ali, M., Wei, J., Wang, H., Yeo, L.Y. Friend, J.R. and MacFarlane, D.R. (2014) UV/Ozone-Assisted Low Temperature Preparation of Mesoporous $\mathrm{TiO}_{2}$ with Tunable Phase Composition and Enhanced Solar Light Photocatalytic Activity. Journal of Materials Chemistry A, 2, 18791-18795.

https://doi.org/10.1039/C4TA04020A

\section{Scientific Research Publishing}

Submit or recommend next manuscript to SCIRP and we will provide best service for you:

Accepting pre-submission inquiries through Email, Facebook, LinkedIn, Twitter, etc. A wide selection of journals (inclusive of 9 subjects, more than 200 journals)

Providing 24-hour high-quality service

User-friendly online submission system

Fair and swift peer-review system

Efficient typesetting and proofreading procedure

Display of the result of downloads and visits, as well as the number of cited articles

Maximum dissemination of your research work

Submit your manuscript at: http://papersubmission.scirp.org/

Or contact ojpc@scirp.org 